\title{
Evaluation of Vermifiltration of Cassava Effluent Using Earthworm
}

\author{
${ }^{* 1}$ AWU, JI; ${ }^{1}$ HENRY, O; ${ }^{1}$ MANTA, HI; ${ }^{1}$ JAMES, DD; ${ }^{2}$ ADEOSUN, OJ \\ ${ }^{*}$ Department of Land and Water Engineering, National Centre for Agricultural Mechanization Ilorin, Kwara State, Nigeria \\ ${ }^{2}$ Department of Agricultural and Bioresources, Federal University of Agriculture Abeokuta, Nigeria \\ *Corresponding Author Email: ecoagricultural@gmail.com
}

\begin{abstract}
The objective of this study was to evaluate the vermifiltration of different cassava effluent concentrations using of earthworms by applying standard methods. Results for physiochemical parameters before treatment ranges from 3.91 to $5.94,28.6$ to $28.7(\mu \mathrm{S} / \mathrm{cm}), 12480$ to $13999(\mathrm{mg} / \mathrm{l}), 7900$ to $9511(\mathrm{mg} / \mathrm{l}), 168$ to $207(\mathrm{mg} / \mathrm{l})$, 8068 to $9718(\mathrm{mg} / \mathrm{l}), 225$ to $284(\mathrm{mg} / \mathrm{l}), 114$ to $132(\mathrm{mg} / \mathrm{l}), 1040$ to $1680(\mathrm{mg} / \mathrm{l}), 400$ to $540(\mathrm{mg} / \mathrm{l}), 52$ to $72(\mathrm{mg} / \mathrm{l}), 24$ to $40(\mathrm{mg} / \mathrm{l}), 20$ to $30(\mathrm{mg} / \mathrm{l}), 33$ to $65(\mathrm{mg} / \mathrm{l})$ for $\mathrm{pH}$, Temperature, EC, TDS, TSS, TS, COD, BOD, Hardness, chlorine, calcium, magnesium, sodium and potassium, respectively, while after treatment ranges from 6.45 to $10.1,28.6$ to 29 , 12021 to $12621(\mu \mathrm{S} / \mathrm{cm}), 8100$ to $9846(\mathrm{mg} / \mathrm{l}), 199$ to $211(\mathrm{mg} / \mathrm{l}), 8299$ to $10057(\mathrm{mg} / \mathrm{l}), 260$ to $291(\mathrm{mg} / \mathrm{l}), 140$ to $120(\mathrm{mg} / \mathrm{l})$, 760 to $1160(\mathrm{mg} / \mathrm{l}), 260$ to $440(\mathrm{mg} / \mathrm{l}), 48$ to $62(\mathrm{mg} / \mathrm{l}), 22$ to $39(\mathrm{mg} / \mathrm{l}), 19$ to $28(\mathrm{mg} / \mathrm{l}), 31$ to $60(\mathrm{mg} / \mathrm{l})$ for $\mathrm{pH}$, Temperature Electrical Conductivity (EC), TDS, TSS, TS, COD, BOD, Hardness, Chlorine, Calcium, Magnesium, Sodium and Potassium, respectively, across the different concentrations $(100 \%, 75 \%, 50 \%$ and $25 \%)$ of cassava effluent. It was therefore, observed that the use of earthworm in the treatment of cassava effluent was effective, though, it could not treat the cassava effluent to the acceptable World Health Organization (WHO) Standards for irrigation use.
\end{abstract}

\section{DOI: https://dx.doi.org/10.4314/jasem.v24i1.5}

Copyright: Copyright $(\mathrm{C} 2020 \mathrm{Awu}$ et al. This is an open access article distributed under the Creative Commons Attribution License (CCL), which permits unrestricted use, distribution, and reproduction in any medium, provided the original work is properly cited.

Dates: Received: 30 November 2019; Revised: 20 December 2019; Accepted: 23 December 2019

Keywords: physiochemical characteristics, cassava, effluent concentrations, vermifiltration

Cassava (Manihot esculanta crantz) is the world's third most important crop and an essential source of food and income throughout the tropics providing livelihood for over five hundred million $(500,000,000)$ people (Awu et. al., 2016). Cassava constitutes a major staple food for over fifty million $(50,000,000)$ Nigerians, providing more than $70 \%$ of their daily energy requirements (Awu et. al., 2016). Nigeria is the world largest producer of cassava; the crop is produced in 24 of the country's 36 states. In 1999, Nigeria produced 33 million tons, while a decade later; it produced approximately 45 million tons, which is almost $19 \%$ of the world production. The average yield of cassava per hectare is about 10.6 tons (Henry, 2019). Cassava is usually propagated by planting short section of stem of about 20 to $25 \mathrm{~cm}$ length (Oboh, 2005). Cassava has the advantage of being available all year round since it can be left on the ground after maturity for up to three years before harvesting without having significant spoilage. Cassava has so much economic importance and can be processed into different products such as garri, fufu, tapioca, flour just to mention but a few. Different cultivars of cassava which abound worldwide mature at different time. However, certain varieties contains large amount of cyanogenic glycosides which can hydrolyzed to hydrocyanic acid (HCN) by their endogenous enzymes when the plant tissue is damaged during harvesting, processing or other mechanical handling (Oboh and Akindahusi, 2003). The two important wastes that are generated during the processing of cassava tubers include cassava peels and the liquid (effluent) squeezed out of the cassava mesh. Studies revealed that the liquid waste (cassava effluent) contains heavy loads of microorganisms, lactic acid, lysine and amylase capable of hydrolyzing the glycosides (Raimbault, 1998). During the processing of cassava tubers to various products, liquid waste generated responsible for several environmental and vegetative degradation. This no doubt has been causing serious environmental pollution as a result of the indiscriminate discharge. Uzochukwu et al., (2001) reported that high level of cassava liquid waste is produce daily and drained onto roads, streets, rivers and agricultural lands in gari producing communities of Nigeria. These singular activities tend to expose the waste water to microbial contamination. The reports of Uzochukwu et al., (2001) also revealed that cassava liquid waste contains fermentable sugars, starch, cellulose, while Oboh and Akindahunsi (2003) documented it to contain cyanogenic glycosides and essential elements such as Zinc (Zn), Magnesium $(\mathrm{Mg})$, Iron $(\mathrm{Fe})$, Calcium $(\mathrm{Ca})$, Sodium $(\mathrm{Na})$ and Potassium (K). 
Vermifiltration is an effective, low cost and environmental friendly process of treating waste water with the help of earthworms and other microorganisms. The idea of vermifiltration has been derived from vermicomposting which is the treatment of the solid waste using earthworms. Generally, the common species of earthworm employed for the vermifiltration are Eiseniafetida, Eudriluseuginea, Lumbricusrebellus (Arora et al., 2015). The mechanism in which the vermifiltration works is that the earthworm acts as bio-filters. They feed on the trapped organic matter on the soil bed present in the sewage and along with the aid of micro-organism (Taylor, 2000) considerably improves the quality of water by bringing down the level of Biological Oxygen Demand (BOD), Chemical Oxygen Demand (COD), Turbidity of the waste water without any skilled supervision and forming any sludge and odour (Arora et. al., 2015). The problem of efficient disposal and management of waste water has become more rigorous due to rapidly increasing population, intensive agriculture and industrialization, over the last few years. The various types of environment and disposal problems caused by the production of large quantities of waste water in Nigeria requires sustainable approach in a cost effective manner and this has become a very important issue for maintaining healthy environment (Edwards and Bater, 1992). Vermifiltration is being considered as a potential option in the hierarchy of waste water management that involves the stabilization of organic material by the joint action of earthworm and microorganisms. Although microbes are responsible for the biochemical degradation of the waste water, earthworms are the important drivers of the process by conditioning the substrate and altering the biological activity (Aora et al., 2007). Vermifiltration is an aerobic treatment system which consists of a biological reactor containing media that filters organic material from waste water. This media also provides a habitat for aerobic bacteria and composting earthworms that produce humus. This process has the capacity of treating cassava liquid waste before it can be safely discharged into the environment. The objective of this study was to determine the physiochemical characteristics of different cassava effluent concentrations before and after vermifiltration

\section{MATERIALS AND METHODS}

Study Area: The study area of this research is Federal University of Agriculture, Abeokuta (FUNAAB) which is located approximately on latitude $7030^{\prime} \mathrm{N}$ and longitude $3054^{\prime}$ E. FUNNAB is next to OgunOsun River Basin Development Authority (OORBDA), along Osiele-Abeokuta road, off Abeokuta-Ibadan road in the north Eastern end of the city at Alabata and is from the city center of Abeokuta which lie (Ufoegbune and Fabiyi, 2016). FUNNAB lies within the humid lowland rain forest region with two distinctive seasons. The wet season extends from March to October while the dry season extends from November to February. The mean annual rainfall is $1113.1 \mathrm{~mm}$ while the mean monthly temperature varies from 22.90C in August to 36.320C in March (Ufoegbune and Fabiyi, 2016). The relative humidity is high ranging from $75.520 \mathrm{C}$ in February to $88.150 \mathrm{C}$ in July (Aiboni, 2001). Map of the study area is shown in figure 1.

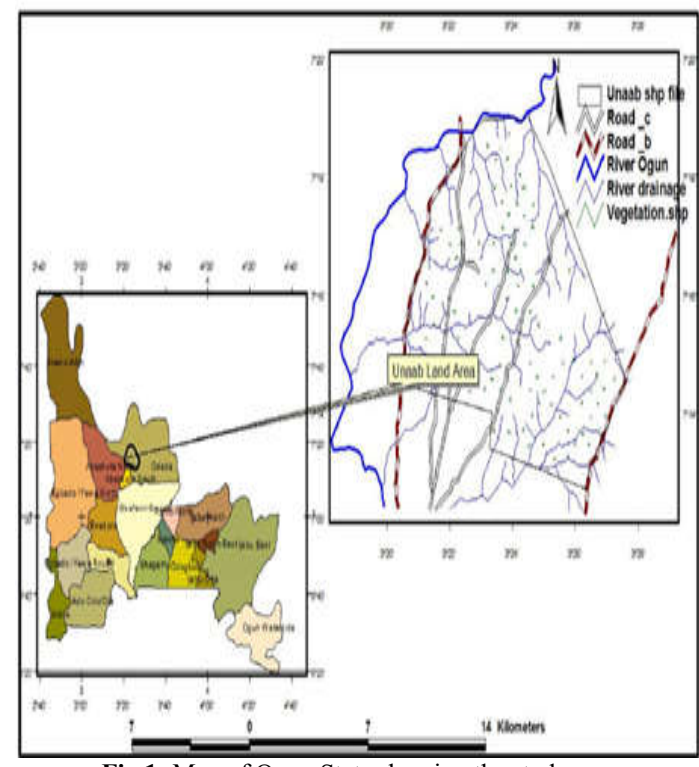

Fig 1: Map of Ogun State showing the study area

Materials: The materials used to carry out this research study include; Worm bin, earthworm (Eisenia Foetida), Cassava waste water, Water bucket, Weigh scale, Distilled water, Soil, Volumetric flask, Kegs, Valves, Bottles, ethylene diamine tetra-acetic acid (EDTA) solution, Hanna combo multimeter. The cassava waste water was collected from a gariprocessing factory at camp community, Abeokuta Ogun State while the earthworms used were gotten by hand picking within the premises of the Federal University of Agriculture Abeokuta (FUNAAB), Ogun State. Experimental Setup: The research study was made up of 8 different experimental setups to determine the effect of vemifiltration on different concentration of the cassava effluent of $100 \%, 75 \%$, $50 \%$ and $25 \%$, respectively. The eight (8) set up was divided into two (2) groups of four setup each. Each setup consisted of Bucket which served as a medium holding rest of the materials such as $1 \mathrm{~kg}$ of soil, $115 \mathrm{~g}$ of earthworm, two (2) litters of water and different concentrations of cassava effluent at $100 \%, 75 \%, 50 \%$ and $25 \%$ respectively. The second group setup had the 
same composition but without earthworm which serves as control to the first group setups.

Physiochemical Parameters Test: Some physiochemical parameters were tests before and after treatment with earthworm and comparison made to the control. The physio-chemical parameters tested include; $\mathrm{pH}$, Temperature, Electrical conductivity (EC), Total Suspended solid (TSS), Total Dissolved Solid (TDS), Total Solid (TS), Chemical Oxygen Demand (COD), Biological Oxygen Demand (BOD), Hardness , Chloride (Cl), Calcium (Ca), Magnesium $(\mathrm{Mg})$, Sodium $(\mathrm{Na})$, Potassium $(\mathrm{K})$.

Parameter Test Procedures: Each parameter test was replicated and an average was taken as the true value of the parameter test. Some physical parameters were determined in-situ using Direct Reading Engineering Method (DREM).

Direct Reading Engineering Method (DREM): This method was used mainly for the analysis of physical parameters such as $\mathrm{pH}$, Temperature, Electrical conductivity (EC), Total Suspended solid (TSS), Total Dissolved Solid (TDS), Total Solid (TS), Chemical Oxygen Demand (COD), Biological Oxygen Demand (BOD). The Hacc Multimeter (model 150) was used to measure these parameters.

Titrimetric Method: This method deals with titrating the cassava effluent sample with Ethylene Diamine Tetra-Acetic Acid (EDTA) solution for Chloride and Hardness

Gravimetric Method: This method was used in determination of Total Suspended Solid (TSS), Total Dissolved Solid (TDS) and Total Solid (TS) respectively. The test procedure was that a glass fiber was dried in oven at $100^{\circ} \mathrm{C}$ to obtain a known constant weight $\mathrm{W} 1$. A $50 \mathrm{ml}$ volume of each cassava effluent sample taken from the experimental setup was filtered through fiber bed. The fiber was dried in a desiccator and weighed immediately to obtain the second weight W2. The total suspended solid concentration was calculated using equation (1)

$T S S=\left(W_{2}-W_{1}\right) / 50$

Where: W2 = weight of solid on the fiber (mg), W1 = weight of the empty dried glass fiber $(\mathrm{mg}), 50=$ volume of cassava effluent sample (ml)

The total solid (TS) was obtained by calculating the arithmetic sum of the total dissolved solid (TDS) and the total suspended solid (TSS) as shown in equation (2).

$$
T S=T D S+T S S
$$

Atomic Absorption Spectrophotometric Method: This method was used in the determination of all the metallic elements such as Magnesium (Mg), Sodium (Na), Potassium (K) and Calcium (Awu et al., 2014). Plate 1 to 4 are not necessary in a research paper and has been deleted

\section{RESULTS AND DISCUSSION}

The results for the vermifiltration of cassava effluent with earthworm and without earthworm are presented in Tables 1 to 3. Likewise, the descriptive graphs of the vermifitration of cassava effluent are shown in Figures 1 to 14 . The use of descriptive graph for analysis was to show the obvious physiochemical parametric differences in the treatment which could not be seen statistically.

Generally, Tables 1 to 3 and Figures 1 to 14 results showed that the use of earthworm in the treatment of cassava effluent was effective, though, it could not treat the cassava effluent to the acceptable World Health Organization (WHO) Standards for irrigation use. It was also generally observed that the earthworms used in the vermifiltration of the cassava effluent died within seventy two (72) hours of the experiment.

Likewise, the results revealed that the vermifiltration of cassava effluent using earthworms was better than without earthworm.

The vermifiltration of the cassava effluent using earthworms performed better on the treatment of Electrical Conductivity (EC), Hardness, Chlorine (Cl), Magnesium (Mg) as shown in Figures 3, 9, 10 and 12, respectively, than other parameters. This agrees to the findings of Arora et. al., (2015).

Also, it was observed that the Chemical Oxygen Demand (COD) and the Biological Oxygen Demand (BOD) increases as the cassava effluent concentrations decreases.

The Physiochemical Parameter Values before Treatment Ranges from 3. 91 To 5.94, 28.6to 28.7(Ms/Cm), 12480 To 13999 (Mg/L), 7900 To 9511(Mg/L), 168 To 207(Mg/L), 8068 To 9718(Mg/L), 225 To 284(Mg/L), 114 To 132(Mg/L), 1040 To $1680(\mathrm{Mg} / \mathrm{L}), \quad 400$ To $540(\mathrm{Mg} / \mathrm{L}), 52$ To 72(Mg/L), 24 To 40(Mg/L), 20 To 30(Mg/L), 33 To $65(\mathrm{Mg} / \mathrm{L})$ For $\mathrm{pH}$, temperature, EC, TDS, TSS, TS, COD, BOD, hardness, chlorine, calcium, magnesium, sodium and potassium, respectively, across different concentrations $(100 \%, 75 \%, 50 \%$ and $25 \%)$ of cassava effluent. 
Full-text Available Online at

J. Appl. Sci. Environ. Manage. https://www.ajol.info/index.php/jasem Vol. 24 (1) 31-36 January 2020 http://ww.bioline.org.br/ja

\begin{tabular}{|c|c|c|c|c|c|c|c|c|c|c|c|c|c|c|}
\hline Sample & pH & Temp. & $\begin{array}{l}\mathbf{E C} \\
(\mu \mathrm{S} / \mathrm{cm})\end{array}$ & $\begin{array}{l}\text { TDS } \\
(\mathrm{mg} / \mathrm{l})\end{array}$ & $\begin{array}{l}\text { TSS } \\
\text { (mg/l) }\end{array}$ & $\begin{array}{l}\text { TS } \\
\text { (mg/l) }\end{array}$ & $\begin{array}{l}\mathrm{COD} \\
(\mathrm{mg} / \mathrm{l})\end{array}$ & $\begin{array}{l}\text { BOD } \\
\text { (mg/l) }\end{array}$ & $\begin{array}{l}\text { Hardness } \\
(\mathrm{mg} / \mathrm{l})\end{array}$ & $\begin{array}{l}\mathrm{Cl} \\
(\mathrm{mg} / \mathrm{l})\end{array}$ & $\begin{array}{l}\mathrm{Ca} \\
(\mathrm{mg} / \mathrm{l})\end{array}$ & $\begin{array}{l}\mathrm{Mg} \\
(\mathrm{mg} / \mathrm{l})\end{array}$ & $\begin{array}{l}\mathrm{Na} \\
(\mathrm{mg} / \mathrm{l})\end{array}$ & $\begin{array}{l}\mathrm{K} \\
(\mathrm{mg} / \mathrm{l})\end{array}$ \\
\hline A & 3.91 & 28.7 & 13999 & 9511 & 207 & 9718 & 225 & 114 & 1680 & 540 & 72 & 40 & 30 & 65 \\
\hline B & 4.93 & 28.7 & 13099 & 9030 & 200 & 9230 & 258 & 119 & 1300 & 460 & 60 & 34 & 28 & 53 \\
\hline $\mathrm{C}$ & 4.94 & 28.6 & 12999 & 8200 & 189 & 8389 & 260 & 127 & 1280 & 420 & 52 & 25 & 25 & 46 \\
\hline D & 5.94 & 28.6 & 12480 & 7900 & 168 & 8068 & 284 & 132 & 1040 & 400 & 52 & 24 & 20 & 33 \\
\hline
\end{tabular}

\begin{tabular}{|c|c|c|c|c|c|c|c|c|c|c|c|c|c|c|}
\hline Sample & pH & Temp. & $\begin{array}{l}\text { EC } \\
(\mu \mathrm{S} / \mathrm{cm})\end{array}$ & $\begin{array}{l}\text { TDS } \\
(\mathrm{mg} / \mathrm{l})\end{array}$ & $\begin{array}{l}\text { TSS } \\
(\mathrm{mg} / \mathrm{l})\end{array}$ & $\begin{array}{l}\text { TS } \\
(\mathrm{mg} / \mathrm{l})\end{array}$ & $\begin{array}{l}\mathrm{COD} \\
(\mathrm{mg} / \mathrm{l})\end{array}$ & $\begin{array}{l}\text { BOD } \\
(\mathrm{mg} / \mathrm{l})\end{array}$ & $\begin{array}{l}\text { Hardness } \\
(\mathrm{mg} / \mathrm{l})\end{array}$ & $\begin{array}{l}\mathrm{Cl} \\
(\mathrm{mg} / \mathrm{l})\end{array}$ & $\begin{array}{l}\mathrm{Ca} \\
(\mathrm{mg} / \mathrm{l})\end{array}$ & $\begin{array}{l}\mathrm{Mg} \\
(\mathrm{mg} / \mathrm{l})\end{array}$ & $\begin{array}{l}\mathrm{Na} \\
(\mathrm{mg} / \mathrm{l})\end{array}$ & $\begin{array}{l}\mathrm{K} \\
(\mathrm{mg} / \mathrm{l})\end{array}$ \\
\hline $\mathrm{A}$ & 6.45 & 28.6 & 12621 & 9846 & 211 & 10057 & 260 & 120 & 1160 & 440 & 62 & 39 & 28 & 60 \\
\hline B & 6.13 & 28.7 & 12090 & 9180 & 200 & 9380 & 265 & 128 & 1040 & 340 & 58 & 32.2 & 25 & 50 \\
\hline $\mathrm{C}$ & 7.73 & 28.9 & 12271 & 8712 & 208 & 8920 & 277 & 137 & 900 & 280 & 50 & 23 & 21 & 45 \\
\hline D & 10.1 & 29 & 12021 & 8100 & 199 & 8299 & 291 & 140 & 760 & 260 & 48 & 22 & 19 & 31 \\
\hline
\end{tabular}

\begin{tabular}{|c|c|c|c|c|c|c|c|c|c|c|c|c|c|c|}
\hline Sample & pH & Temp. & $\begin{array}{l}\mathbf{E C} \\
(\mu \mathrm{S} / \mathrm{cm})\end{array}$ & $\begin{array}{l}\text { TDS } \\
(\mathrm{mg} / \mathrm{l})\end{array}$ & $\begin{array}{l}\text { TSS } \\
(\mathrm{mg} / \mathrm{l})\end{array}$ & $\begin{array}{l}\text { TS } \\
(\mathrm{mg} / \mathrm{l})\end{array}$ & $\begin{array}{l}\text { COD } \\
(\mathrm{mg} / \mathrm{l})\end{array}$ & $\begin{array}{l}\text { BOD } \\
(\mathrm{mg} / \mathrm{l})\end{array}$ & $\begin{array}{l}\text { Hardness } \\
(\mathrm{mg} / \mathrm{l})\end{array}$ & $\begin{array}{l}\mathrm{Cl} \\
(\mathrm{mg} / \mathrm{l})\end{array}$ & $\begin{array}{l}\mathrm{Ca} \\
(\mathrm{mg} / \mathrm{l})\end{array}$ & $\begin{array}{l}\mathrm{Mg} \\
(\mathrm{mg} / \mathrm{l})\end{array}$ & $\begin{array}{l}\mathrm{Na} \\
(\mathrm{mg} / \mathrm{l})\end{array}$ & $\begin{array}{l}\mathrm{K} \\
(\mathrm{mg} / \mathrm{l})\end{array}$ \\
\hline A & 6.36 & 28.9 & 13029 & 9825 & 223 & 10048 & 253 & 118 & 1700 & 1660 & 66 & 31 & 29 & 64 \\
\hline B & 6.61 & 29.1 & 13000 & 9108 & 223 & 9331 & 260 & 120 & 1380 & 1940 & 58.5 & 52 & 27 & 51 \\
\hline $\mathrm{C}$ & 7.1 & 29.1 & 12770 & 8500 & 226 & 8726 & 265 & 126 & 1300 & 400 & 51 & 53 & 23 & 45.5 \\
\hline D & 9.04 & 29.1 & 12100 & 8002 & 203 & 8205 & 290 & 130 & 1000 & 560 & 49 & 60 & 20 & 32 \\
\hline
\end{tabular}

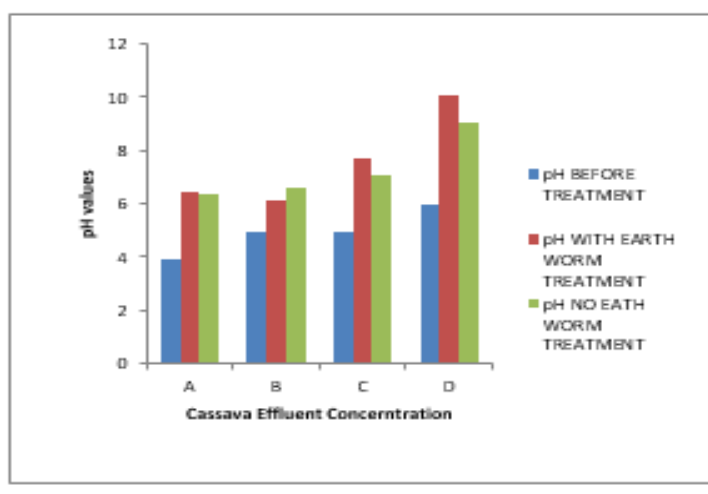

Fig. 2: $\mathrm{pH}$ values of the cassava effluent

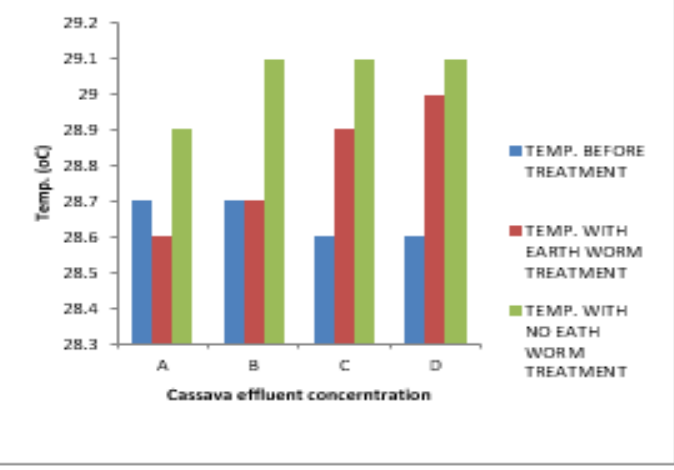

Fig. 3: Temp. Values of the cassava effluent 
PRINT ISSN 1119-8362

Electronic ISSN 1119-8362
Full-text Available Online at https://www.ajol.info/index.php/jasem http://ww.bioline.org.br/ja
J. Appl. Sci. Environ. Manage. Vol. 24 (1) 31-36 January 2020

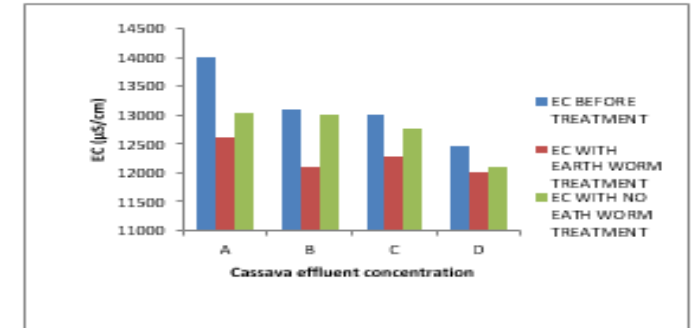

Fig. 4: EC values of the cassava effluent
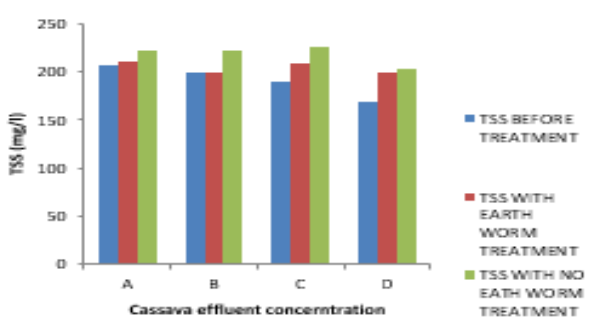

Fig. 6: TSS values of the cassava effluent

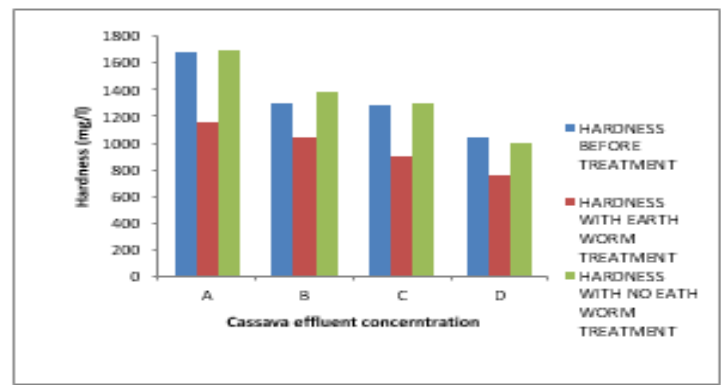

Fig. 10: Hardness values of the cassava effluent

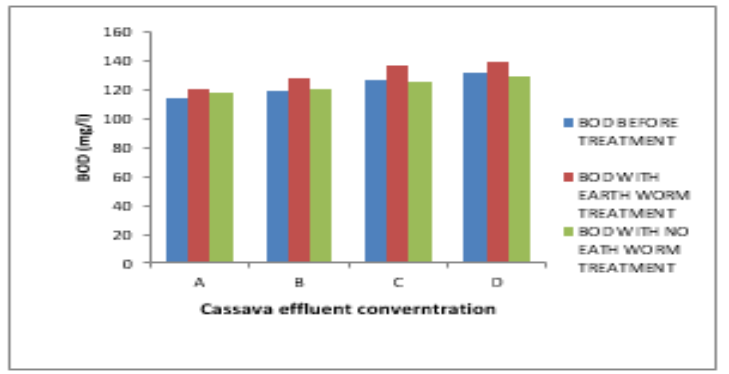

Fig. 8: BOD values of the cassava effluent

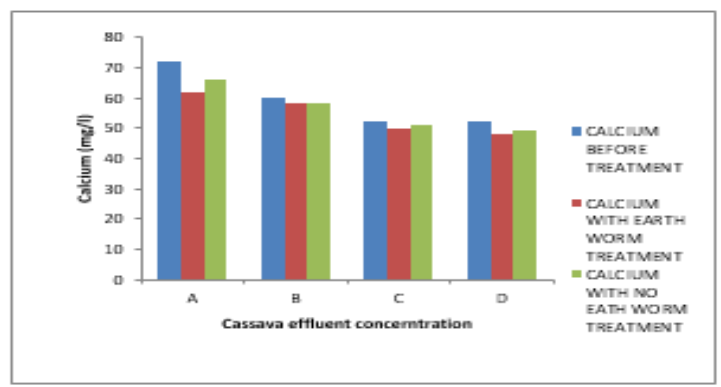

Fig. 12: Calcium values of the cassava effluent

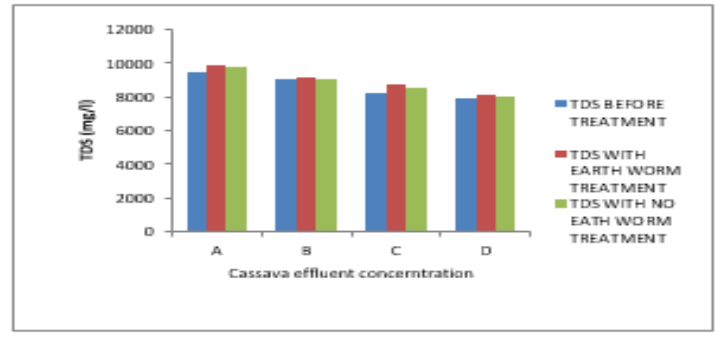

Fig. 5: TDS Values of the cassava effluent

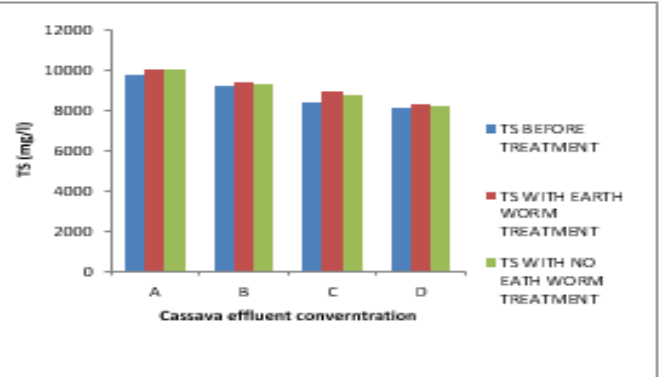

Fig. 7: TS Values of the cassava effluent

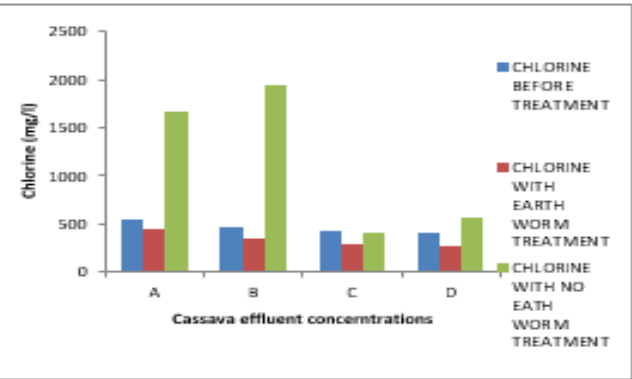

Fig. 11: Chlorine Values of the cassava effluent

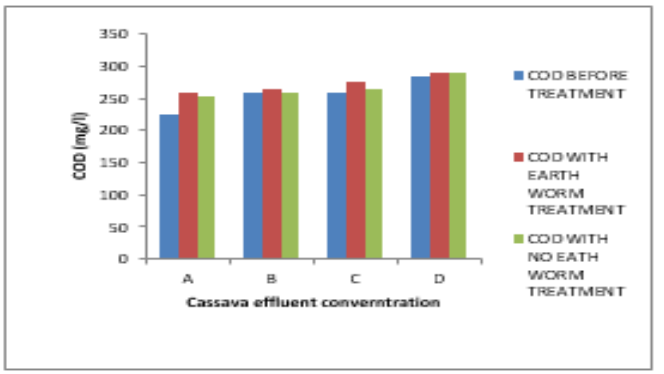

Fig. 9: COD Values of the cassava effluent

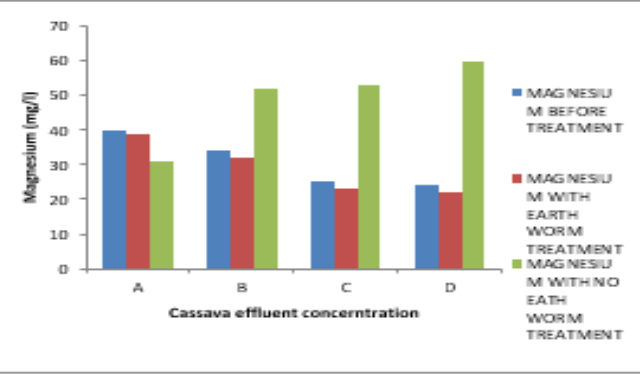

Fig. 13: Magnesium Values of the cassava effluent 


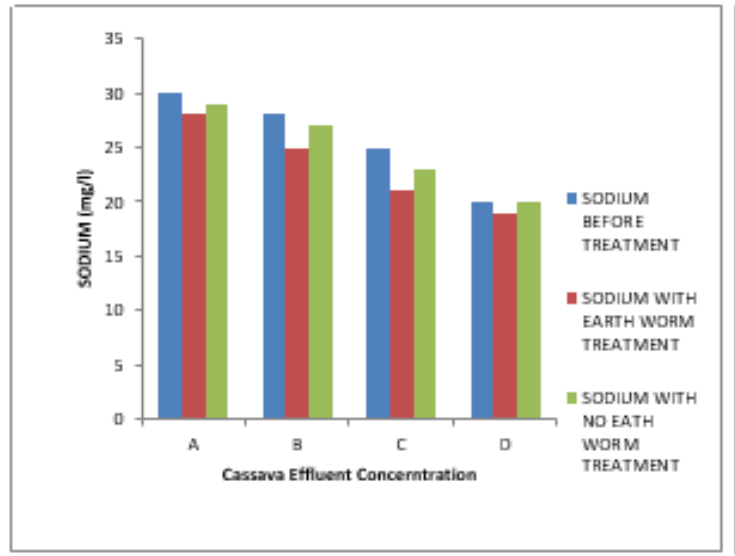

Fig. 14: Sodium values of the cassava effluent

More so, the physiochemical parameter values after treatment ranges from 6.45 to $10.1,28.6$ to 29,12021 to $12621(\mu \mathrm{s} / \mathrm{cm}), \quad 8100$ to $9846(\mathrm{mg} / \mathrm{l}), \quad 199$ to $211(\mathrm{mg} / \mathrm{l}), 8299$ to $10057(\mathrm{mg} / \mathrm{l}), 260$ to $291(\mathrm{mg} / \mathrm{l}), 140$ to $120(\mathrm{mg} / \mathrm{l}), 760$ to $1160(\mathrm{mg} / \mathrm{l}), 260$ to $440(\mathrm{mg} / \mathrm{l}), 48$ to $62(\mathrm{mg} / \mathrm{l}), 22$ to $39(\mathrm{mg} / \mathrm{l}), 19$ to $28(\mathrm{mg} / \mathrm{l}), 31$ to $60(\mathrm{mg} / \mathrm{l})$ for $\mathrm{pH}$, temperature, electrical conductivity (EC), TDS, TSS, TS, COD, BOD, hardness, chlorine, calcium, magnesium, sodium and potassium, respectively, across different concentrations (100\%, $75 \%, 50 \%$ and $25 \%$ ) of cassava effluent. More so, the physiochemical parameter values after treatment ranges from 6.45 to $10.1,28.6$ to 29,12021 to $12621(\mu \mathrm{s} / \mathrm{cm}), 8100$ to $9846(\mathrm{mg} / \mathrm{l}), 199$ to $211(\mathrm{mg} / \mathrm{l})$, 8299 to $10057(\mathrm{mg} / \mathrm{l}), 260$ to $291(\mathrm{mg} / \mathrm{l}), 140$ to $120(\mathrm{mg} / \mathrm{l}), 760$ to $1160(\mathrm{mg} / \mathrm{l}), 260$ to $440(\mathrm{mg} / \mathrm{l}), 48$ to $62(\mathrm{mg} / \mathrm{l}), 22$ to $39(\mathrm{mg} / \mathrm{l}), 19$ to $28(\mathrm{mg} / \mathrm{l}), 31$ to $60(\mathrm{mg} / \mathrm{l})$ for $\mathrm{pH}$, temperature, electrical conductivity (EC), TDS, TSS, TS, COD, BOD, hardness, chlorine, calcium, magnesium, sodium and potassium, respectively, across different concentrations (100\%, $75 \%, 50 \%$ and $25 \%$ ) of cassava effluent.

Conclusion: effluents from cassava processing have been causing serious environmental pollution. Vermifiltration method using earthworms was employed in this study to treat different concentrations of cassava effluent. Results from study showed that the use of earthworm in the treatment of cassava effluent was effective, though, it could not treat the cassava effluent to the acceptable world health organization standards for irrigation use. Information guarded from study will help in policy and management of environmental pollution.

\section{REFERENCES}

Arora, S; Bhargavab, R; Kazmib, A; Kumara, T; Prasad, K; Rajpal, A (201). Antibacterial and

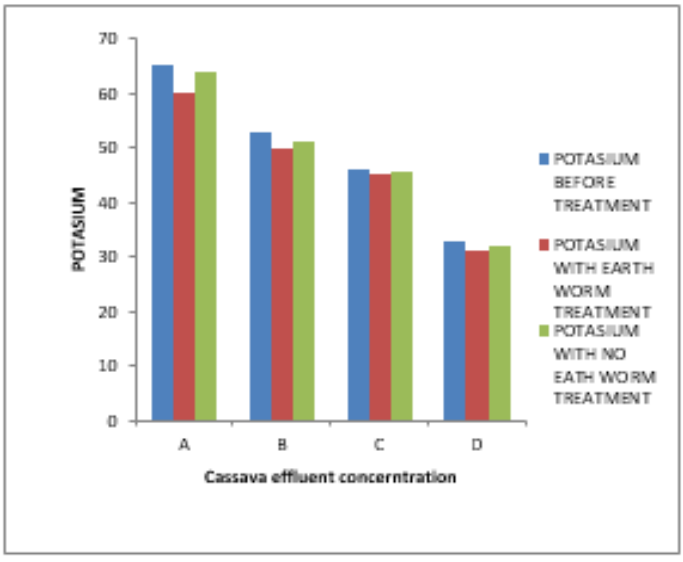

Fig. 15: Potassium Values of the cassava effluent

Enzymatic Activity of Microbial Community During Waste Water Treatment By Pilot Scale Vermifiltration System. Bio-Resource Technology 166,132-141.

Edwards, C A; Fletcher, KE (1988). Interaction Between Earthworms And Microorganisms In Organic Matter Breakdown. Agri Ecosystem Environment 24:235-247.

Oboh, G; Akindahunsi, AA (2003). Chemical Changes In Cassava Peels Fermented With Mixed Cultured Of Aspergillusniger And Two Species Of Lactobacillus Integrated Bio-System. Applied Trop. Agric., 8: 63-68.

Oboh, G (2005). Isolation and Characterization Of Amylase From Fermented Cassava (Manihot Esculenta Crantz) Wastewater. Afr. J. Biotechnol., 4: 1117-1123.

Raimbault, M (1998). General and Microbiology Aspect of Solid Substrate Fermentation. Elect. J. Biotechnol, 1: 26-27.

Taylor, S (2003). The Treatment of Domestic Waste Water Using Small-Scale Vermicomposit Filter Beds. Ecol. Engin. 21:197-203.

Ufoegbune, GC; Fabiyi, S (2016). Identification of Land Areas Suitable For Fadama Farming at Federal University of Agriculture, Abeokuta, Nigeria Using GIS. J. Appl. Sci. Environ. Manage. 20 (4) 1027 - 1032

Uzochukwu, SVA; Oyede, R; Atanda O (2001).Utilization Of Gari Industry Effluent in the Preparation of Gin. Nig. J. Microbiol. 15: 87-92. 